\title{
Alenka Cedilnik
}

\section{Zgodovinsko ozadje Seneki pripisane Oktavije}

Prispevek predstavlja zgodovinsko ozadje Seneki pripisanega dramskega dela Oktavija. V njem nam neznani avtor ${ }^{1}$ slika žalostno usodo Neronove prve žene Oktavije, ki je bila zaradi Neronove poroke s Popejo Sabino najprej izgnana in kmalu zatem v izgnanstvu usmrčena. Osnovno dogajanje dramskega dela v veliki meri zvesto sledi temu, kar nam o življenjski usodi v drami predstavljenih protagonistov povedo tudi ohranjeni zgodovinski viri, ${ }^{2}$ pri čemer je dramsko dogajanje strnjeno $\mathrm{v}$ čas treh dni, v resnici pa ni znano, kako natančno so si sledili dogodki, povezani z Neronovo poroko s Popejo in z njegovo ločitvijo od Oktavije. ${ }^{3}$

Da bi zgodovinsko ozadje obravnavane tragedije lahko čim bolje razumeli, se najprej ustavimo v letu 47. Tega leta je bila kot žrtev spletk žene takratnega cesarja Klavdija, Mesaline, usmrčena Popeja Sabina, mati enako imenovane Neronove druge žene Popeje Sabine. ${ }^{4}$ Leta 30 rojeni Popeji Sabini (Mlajši) je bilo ob tem dogodku 17 let in je najverjetneje zelo dobro vedela, kdo je kriv za smrt njene matere. Zato si lahko predstavljamo, da Oktaviji,

1 Delo je najverjetneje nastalo v prvih letih Vespazijanove vlade (med letom 69 in sredo sedemdesetih let); gl. Pseudo-Seneca, Octavia, xiv-xvi; Cizek, L'époque de Néro, 361.

2 Tacitus, Annales 13-16 (za obdobje od 54 do 66); Suetonius, Nero; Cassius Dio 61-63; med poznimi viri Eutropius 7.14-15; Aurelius Victor, Caesares 5; Epitome 5; Orosius 7.7; Zonaras 11.12-13. Gl. tudi uvodno študijo, ki jo je napisal A. J. Boyle v: Pseudo-Seneca, Octavia, lviii.

3 Glede na to, da je Popeja Neronu rodila hčer 21. januarja leta 63, je moralo biti maja leta 62 že jasno, da je noseča. Oktavija je bila usmrčena junija leta 62. Iz virov pa ni mogoče razbrati, ali je Neron Oktavijo odslovil in jo poslal v njeno prvo izgnanstvo v Kampanijo šele, ko je izvedel za Popejino nosečnost ali že pred tem, kakor tudi ne, ali se je Neron s Popejo poročil še pred Oktavijino usmrtitvijo ali šele po njej. Gl. tudi Waldherr, Nero, 101. Edini avtor, ki zaporedje dogodkov časovno deloma opredeljuje, je Svetonij (Nero 35.3: Poppaeam duodecimo die post divortium Octaviae in matrimonium acceptam dilexit unice;...). Vendar tudi njegov podatek, da se je Neron s Popejo poročil dvanajsti dan po ločitvi od Oktavije, ne more razjasniti zgoraj navedene nejasnosti.

4 Tacitus, Annales 11.1-3. Gl. tudi Eck, »Iulisch-claudische Familie«, 127-28. 
tedaj osemletni hčerki Mesaline in cesarja Klavdija, od tega dogodka dalje ni bila naklonjena, morda pa jo je že tedaj povsem zavestno zasovražila. Noben izmed ohranjenih virov te možnosti izvora Popejinega sovraštva do Oktavije posebej ne izpostavlja, pa vendar smo lahko skoraj prepričani, da ob kasnejšem rivalstvu med obema ženama ta tedaj že nekoliko oddaljeni dogodek na celotno dogajanje ni imel blagodejnega vpliva.

Kolikor lahko dogajanju sledimo na osnovi zgodovinskih virov, sta se po letu 47 življenjski poti Oktavije in Popeje Sabine znova usodneje prepletli leta 58. Za to leto imamo namreč prva poročila o tem, da je Popeja Sabina, ki je tako kot že njena mama veljala za eno največjih lepotic svojega časa, s svojo lepoto povsem omrežila tedanjega cesarja Nerona. Ta pa ni bil več samski, marveč od leta 53 poročen z Oktavijo, hčerko svojega tedaj že štiri leta pokojnega adoptivnega očeta, cesarja Klavdija, s katero ga je vezalo tudi krvno sorodstvo. Neronova mati, Agripina Mlajša, je bila namreč nečakinja svojega moža in Oktavijinega očeta, cesarja Klavdija. Tako Neron ni bil le Klavdijev adoptivni sin, ampak tudi nečak v drugem kolenu, saj sta bila njegov ded Germanik in cesar Klavdij brata.

A za Oktavijo so težki časi nastopili že na začetku leta 49, ko se je njen oče cesar Klavdij, po usmrtitvi svoje tretje žene Valerije Mesaline ${ }^{5}$ v oktobru leta 48, poročil s svojo nečakinjo Agripino Mlajšo. Zaradi bližnjega sorodstva med cesarjem in njegovo novo ženo so morali še pred poroko deloma spremeniti zakone, ki dotlej niso dovoljevali porok stricev z nečakinjami. ${ }^{6}$ Še preden pa si je Agripina s poroko zagotovila mesto ob takratnem cesarju, je že začela pripravljati pot, ki bi njenega sina, Lucija Domicija Ahenobarba, ${ }^{7}$ kasnejšega Nerona, pripeljala na mesto naslednika trenutnega cesarja. $\mathrm{V}$ ta namen je $\mathrm{s}$ pomočjo cenzorja Lucija Vitelija na osnovi sramotnih obtožb ${ }^{8}$ dosegla, da je bil Lucij Junij Silan, ${ }^{9}$ tako kot Agripinin sin Avgustov prapravnuk, ki je bil že od leta $41^{10}$ zaročen z Oktavijo, izključen iz senata. Hkrati je Klavdij prekinil njegovo zaroko s svojo hčerko ter Silana prisilil, da se je še tik pred iztekom

5 V Seneki pripisani tragediji Oktavija naslovna junakinja objokuje ravnanje svoje matere in njeno smrt, ki je predstavljala uvod v njeno lastno žalostno usodo; gl. Pseudo-Seneca, Octavia, 1020, 257-69.

6 Tacitus, Annales 12.6-7; Cassius Dio 61[6o].31.8. Gl. tudi Eck, »Iulisch-claudische Familie«, 142; Waldherr, Nero, 37. O posledicah nove poroke z Agripino je zagotovo temeljito premislil tudi Klavdij. Bodoči Neron, Agripinin sin, je bil namreč po materini strani Avgustov prapravnuk, medtem ko samega Klavdija z Avgustom ni vezalo krvno sorodstvo. Zato J. Malitz domneva, da je poroka s tem, ko je Klavdiju v večji meri omogočila nadzirati Agripinine ambicije, zelo koristila tudi samemu cesarju. Katerikoli drug Agripinin novi mož bi namreč kot očim takrat vse bolj priljubljenega Nerona Klavdijevi oblasti lahko predstavljal resno nevarnost; gl. Malitz, Nero, 12.

7 Neronov oče je bil Cn. Domitius Ahenobarbus.

8 Lucij Junij Silan je bil obtožen krvoskrunskega razmerja s svojo sestro Junijo Kalvino; gl. tudi Waldherr, Nero, 42-43.

9 Bil je sin Marka Junija Silana Torkvata, konzula leta 19, in Emilije Lepide, Avgustove pravnukinje. Poleg Lucija Junija Silana so se zakoncema rodili še štirje otroci, dva sinova in dve hčerki: Decim Junij Silan Torkvat, Mark Junij Silan, Junija Kalvina in Junija Lepida. Po materini strani so bili tako kot Neron Avgustovi prapravnuki, kar je bil razlog za to, da so zaradi Agripininega in Neronovega strahu pred izgubo oblasti vsi trpeli.

10 Gl. komentar Ericha Koestermanna k mestu 12.3.2 v Tacitus, Annalen, 112. 
leta odrekel pretorski funkciji, ki jo je opravljal v letu $48 .{ }^{11} \mathrm{Kmalu}$ zatem si je Silan, kot poroča Tacit, na dan poroke med cesarjem Klavdijem in Agripino sam vzel življenje. ${ }^{12}$ Po odstranitvi Silana je Klavdij na prošnjo nekdanjega konzula Memija Poliona hčer Oktavijo zaročil z Agripininim sinom Domicijem Ahenobarbom. ${ }^{13}$ Tako Agripinin sin s cesarjem ni bil le sorodstveno povezan, temveč je postal tudi njegov bodoči zet, kar je Domicijev položaj še bolj približalo položaju Klavdijevega sina Britanika iz njegovega zakona z Mesalino.

Vendar Agripini to ni zadoščalo. Da bi sinu zagotovila vladarsko prihodnost, je leta 49 za njegovega vzgojitelja postavila filozofa Lucija Aneja Seneko. Njena odločitev je bila dobro premišljena. Seneka ni bil le eden največjih intelektualcev svojega časa, marveč ga je z Agripino povezovalo tudi čustvo globoke hvaležnosti. Prav njej je namreč dolgoval zahvalo za to, da se je po osmih letih izgnanstva, v katerega ga je zaradi razmerja $\mathrm{z}$ Agripinino sestro Julijo Livilo na pobudo Mesaline poslal cesar Klavdij, ${ }^{14}$ znova lahko vrnil v prestolno mesto. To pa ni bilo vse. Kakor je Agripina lahko pričakovala, da ji bo Seneka zaradi rešitve vedno naklonjeno vdan, tako je lahko domnevala, da Klavdiju povzročene mu nesreče nikoli ne bo odpustil. ${ }^{15}$ In res je Seneka še po cesarjevi smrti do Klavdija gojil prav nič filozofsko nepomirljivo sovraštvo. ${ }^{16}$

Približno leto dni po sklenitvi zaroke z Oktavijo je Agripini sinov položaj uspelo dodatno okrepiti in zavarovati, ko je 25 . februarja leta 50 njen sin Domicij Ahenobarb z adopcijo postal cesarjev posinovljenec. ${ }^{17}$ Od tedaj naprej je bilo Domicijevo uradno ime Neron Klavdij Cezar Druz Germanik in s pravnega vidika za nasledstvo adoptivnega očeta ni imel prav nič manjših možnosti kot Klavdijev biološki sin Britanik. Ker pa je bil Neron od Britanika nekaj let starejši ${ }^{18}$ je dejansko postal celo prvi kandidat. ${ }^{19}$ Kot lahko raz-

11 Tacitus, Annales 12.3-4; Pseudo-Seneca, Octavia, 145-49. O prekinitvi Oktavijine zaroke s Silanom poroča tudi Kasij Dion (61[6o].31.8), ki pa drugače kot Tacit kot razlog za Silanov padec navaja obtožbo, da je snoval zaroto proti Klavdiju. Lažna obtožba naj bi Klavdija prepričala, da je dal Silana usmrtiti.

12 Tacitus, Annales 12.8.1.

13 Tacitus, Annales 12.9; Cassius Dio 61[6o].32.2.

14 O vzrokih Senekinega izgnanstva gl. Waldherr, Nero, 44-45.

$15 \mathrm{~V}$ nasprotju s to možnostjo Anthony A. Barrett domneva, da Agripinini cilji, povezani s krepitvijo njenega in Neronovega položaja, niso bili v nasprotju s Klavdijevimi interesi, saj naj bi služili zgolj temu, da se julijski in klavdijski rod tesneje povežeta in tako okrepljena utrdita svojo politično moč. Zato Senekino sovraštvo do Klavdija Seneki takrat ne bi moglo koristiti in ga je Seneka skrbno prikrival; gl. Barrett, Agrippina, 102-106.

$16 \mathrm{Ob}$ Klavdijevi smrti je Seneka napisal govor z naslovom Apocolocyntosis, v katerem je umrlega cesarja neusmiljeno sramotil; gl. Cassius Dio 61.35.3. Spis je preveden tudi v slovenščino; gl. »Potikvitev. Satira na cesarja Klaudija smrt, vnebohod in pot v pekel.« Prev. A. Sovre. V: Svet humorja in satire, ur. D. Ravljen. Ljubljana: Društvo novinarjev Slovenije, 1951, 9-23. Namene, ki so Seneko ob pisanju spisa vodili, podrobneje predstavlja Cizek, L'époque de Néro, 78-86.

17 Tacitus, Annales 12.25-26; Cassius Dio 61[6o].32.2.

18 Britanik se je kot sin Klavdija in Valerije Mesaline rodil 11. ali 12. februarja leta 41, Neron pa je bil rojen več kot tri leta pred njim, 15. decembra leta 37; gl. Kienast, Römische Kaisertabelle, 93 in 96.

19 Eck, »Iulisch-claudische Familie«, 144. Barrett domneva, da Klavdijeva naklonjenost Neronu ni bila posledica cesarjeve omejenosti in nepremišljene poslušnosti Agripini, temveč naj bi cesar 
beremo iz ohranjenih virov, prednost, ki jo je tako dobil posinovljeni Neron pred bratom Britanikom, $v$ javnosti ni sprožila odkritega nasprotovanja, čeprav Tacit piše, da takrat ni bilo nikogar, ki ga ne bi bolela Britanikova usoda. ${ }^{20}$ Med Klavdijeve tesnejše sodelavce je možnost, da bi slednjega nasledil Neron in ne Britanik, morda celo prinesla rahlo olajšanje, saj je bil del njih vpleten $\mathrm{v}$ odstranitev Britanikove matere Mesaline in je zato s strahom pričakoval, kakšno bi lahko bilo Britanikovo maščevanje, če bi nekoč zasedel vladarski prestol. ${ }^{21}$

Z adopcijo Agripina ni dosegla zgolj tega, da je svojemu sinu skorajda že zagotovila mesto cesarja, temveč se je močno okrepil tudi njen lastni položaj, ki ga je imela na dvoru. Kot prva med ženami cesarjev je še v času moževega življenja dobila častni naziv avgusta. ${ }^{22}$ To čast si je zaslužila, ker je Klavdiju podarila novega sina. Kako spretno je Agripina krepila svojo moč, kaže dejstvo, da je prav Klavdij, potem ko mu je Mesalina rodila sina Britanika, zavrnil enako pobudo senata, ki je ob Britanikovem rojstvu z nazivom avgusta želel počastiti že Mesalino.

Tej časti so sledili dogodki, ki so še okrepili Agripinin in Neronov položaj na dvoru ter postavljali v ospredje Nerona, medtem ko je Britanik drsel v ozadje. Marca ${ }^{23}$ leta 51 je Neron, čeprav mu takrat niti še ni bilo 14 let, prejel moško togo (toga virilis), kar je pomenilo, da velja za polnoletnega in lahko kot mož prevzame zadolžitve, povezane $\mathrm{z}$ upravljanjem države. ${ }^{24} \mathrm{~S}$ tem so vsaj za leto dni prehiteli običaje, po katerih so dečki deško togo navadno odložili med 15. in 18. letom. V istem mesecu (4. marca) mu je bila po sklepu senata dana možnost, da svoj prvi konzulat nastopi že v svojem dvajsetem letu starosti (torej leta 56). Hkrati je že tedaj prejel prokonzularno oblast nad ozemljem izven Rima, nekoliko kasneje pa - tako kot Avgustova posinovljenca Gaj in Lucij Cezar - še naziv princeps iuventutis. Na ta način je postalo povsem jasno, da je Neron predvideni Klavdijev naslednik. Neron je bil poleg tega vključen $\mathrm{v}$ vse štiri najpomembnejše svečeniške kolegije, njegov posebni položaj pa so propagirali tudi zlati novci. Ker so te izplačevali predvsem vojakom, so tako pri vojski kupovali naklonjenost do predvidenega bodočega vladarja. ${ }^{25}$

morda iz dveh razlogov pri tem ravnal s premišljeno preračunljivostjo. Obstaja namreč možnost, da je Britanik bolehal za hudo obliko epilepsije (Tacitus, Annales 13.16.3) in da v resnici sploh ni bil Klavdijev sin. Vendar pa iz virov prav nikjer ni mogoče razbrati, da bi se Klavdij zaradi morebitnega dvoma v svoje očetovstvo od Britanika kakorkoli osebno odvrnil; gl. Barrett, Agrippina, 111-12.

20 Tacitus, Annales 12.26.2.

21 Cassius Dio 61[6o].31.8. O možnosti, da se je marsikdo iz cesarjeve najbližje okolice zaradi sodelovanja pri strmoglavljenju Mesaline bal Britanikovega maščevanja, gl. tudi Eck, »Iulisch-claudische Familie«, 144-45; Waldherr, Nero, 48.

22 Gl. Koestermannov komentar k odlomku 12.26.1 v Tacitus, Annalen, 151-52; Eck, »Iulisch-claudische Familie«, 145; Shotter, Nero, 13.

23 Barrett domneva, da so pri Neronu slovesnost pripravili že nekoliko pred praznikom Liberalij v marcu, kot je bilo sicer običajno; gl. Barrett, Agrippina, 116.

24 Tacitus, Annales 12.41; Suetonius, Nero 7.2. Gl. tudi Koestermannov komentar k navedenemu mestu v Tacitus, Annalen, 177-79.

25 Tacitus, Annales 12.41. Gl. tudi Eck, »Iulisch-claudische Familie«, 147; Shotter, Nero, 13. 
Klavdijev biološki sin Britanik ni bil deležen nobene od navedenih časti, pri čemer ostaja nejasno, kaj je bil pravi razlog za njegovo zapostavljanje. Čeprav ni nobenih povsem zanesljivih podatkov, ki bi kazali na kakršnekoli značajske pomanjkljivosti ali na Britanikovo nesposobnost za vladanje, te možnosti vendarle ne moremo povsem izključiti. Ko je Britanik po zaužitem strupu izgubil nadzor nad svojim telesom in so navzoči z grozo opazovali, kako v mukah umira, je Neron Britanikovo trpljenje pojasnil kot napad epilepsije, za katero naj bi Britanik že dolgo bolehal. ${ }^{26} \mathrm{Da}$ bi bil Klavdijev sin lahko resno bolan, bi lahko sklepali tudi na podlagi Svetonijevega in Dionovega pisanja. ${ }^{27}$ Vendar nihče, niti Svetonij niti Kasij Dion niti Tacit, za takšno možnost ne nudi zanesljivih dokazov. Kljub temu bi si le stežka predstavljali, da bi bila zgolj Agripinina sla po oblasti tista, ki je Nerona povzdignila na prestol in ugonobila njegovega brata Britanika. ${ }^{28}$ Bolj verjetno se zdi, da je Klavdij v prepričanju, da deluje v dobro vladajoče družine, Agripinin načrt zavestno podpiral in z namenom, da bi zavaroval interese julijsko-klavdijske dinastije, Nerona vključil kot možnega naslednika. ${ }^{29}$

Takšno ravnanje je leta 51 med Neronom in Britanikom sprožilo prvi resni konflikt, ko Britanik Nerona kljub adopciji ni pozdravil z njegovim novim imenom, temveč s starim imenom Domicij. Ker je Agripina v tem videla začetek možnega razdora znotraj družine, je Klavdija pregovorila, naj Britanikove dotedanje učitelje in vzgojitelje zaradi njihovega slabega vpliva odstrani in jih nadomesti z novimi. Tako je Britanik na dvoru izgubil oporo ljudi, ki so bili še vedno naklonjeni Mesalini in so varovali interese njenih otrok. ${ }^{30}$

Dve leti kasneje, leta 53, je Agripina izpeljala še en, sicer že nekaj let načrtovan dogodek. Tega leta se je takrat šestnajstletni Neron poročil s štirinajstletno Oktavijo. Ker sta bila po zakonu Neron in Oktavija brat in sestra, je dal Klavdij še pred poroko Oktavijo posvojiti drugi družini..$^{31} \mathrm{O}$ samem dogodku viri le zelo na kratko poročajo, ${ }^{32}$ zato pa Tacit toliko podrobneje popi-

26 Koestermann domneva, da je Neron bolezen, za katero naj bi Britanik v resnici bolehal, uporabil za laž, s katero je prikril storjeni zločin; gl. komentar k mestu 16.3 v Tacitus, Annalen, 265.

27 Tacitus, Annales 13.16.3; Suetonius, Nero 33.3, Titus 2; Cassius Dion 61[6o].33.10.

28 Eck, »Iulisch-claudische Familie«, 147-48.

29 Glede možnosti, da je Klavdij Nerona kot možnega naslednika določil šele po tehtnem premisleku, gl. tudi Waldherr, Nero, 48-49. Najverjetneje se je šestdesetletni cesar zavedal nevarnosti, da se mu lahko življenje nepričakovano izteče, še preden bi bil njegov sin Britanik dovolj star, da bi sam zasedel njegovo mesto. V tem primeru bi lahko nekoliko starejši Neron, o čigar priljubljenosti v javnosti ni bilo nobenega dvoma, uspešno zapolnil praznino in tako cesarsko oblast ohranil julijsko-klavdijski dinastiji.

30 Tacitus, Annales 12.41.3; Suetonius, Nero 7.1. Gl. tudi Barrett, Agrippina, 118.

31 Cassius Dio 61[6o].33.2. ${ }^{2}$ Barrett, Agrippina, 135. Oktavijo je posvojila ugledna aristokratska družina Oktavijcev, ki ji je pripadal tudi cesar Avgust. Šele takrat je trinajstletno dekle tudi dobilo ime Oktavija, saj se je pred tem kot pripadnica družine Klavdijcev najverjetneje imenovala Klavdija. S posvojitvijo Oktavija formalno ni več pripadala vladajoči družini in z Neronom ni bila več v sorodu; gl. Waldherr, Nero, 58.

32 Suetonius, Nero 7.2; Cassius Dio 61[60].33.11. Kot dogodek, do katerega je prišlo proti Oktavijini volji, poroko z Neronom predstavlja Pseudo-Seneca, Octavia, 150-54. 
suje spremljajoče dogajanje, ki je bilo znova namenjeno izključno dvigovanju ugleda in priljubljenosti predvidenega bodočega cesarja.33

Takrat pa, vsaj zdi se tako, se je moralo v Agripininih skrbno premišljenih načrtih nekaj rahlo zalomiti. Čeprav ne razpolagamo z oprijemljivimi dokazi, bi morda lahko domnevali, da se je Agripina počutila vse bolj ogroženo. Bližal se je februar leta 54, ko bi Britanik stopil v svoje štirinajsto leto in tako lahko dosegel polnoletnost. Tedaj bi lahko Klavdij svojemu sinu Britaniku podelil vse tiste časti, ki jih je bil ob tej priložnosti že deležen Neron, in položaj obeh bi bil znova izenačen. ${ }^{34} \mathrm{Da}$ Agripinine in Neronove prihodnosti prav nič ne bi moglo več ogroziti, je moral zato kot prva žrtev znotraj najožjega družinskega kroga 13. oktobra leta 54 umreti cesar Klavdij, ${ }^{35} \mathrm{ki}$ bi edini Agripininim načrtom lahko prekrižal pot. ${ }^{6}$ Ko so se vrata palače, ki jih je dala Agripina zaradi nemotenih priprav na prevzem oblasti zapreti, znova odprla, je bil Neron kot novi cesar najprej predstavljen pretorijanski gardi in nato še senatu.

Tako je Oktavija postala cesarjeva žena, s čimer pa njen položaj ni bil prav v ničemer lažji, kot je bil dotlej. V palači je zavladala Agripina, ki si je v prvih dneh Neronove vladavine, kot kaže, celo prizadevala, da bi sama zavladala celotnemu cesarstvu. ${ }^{37}$ Ta želja se Agripini ni izpolnila in Neron, ki je imel ob prevzemu oblasti 17 let, se je postopoma izmikal materinemu vplivu. Pač pa so bila prva leta njegovega vladanja pod močnim vplivom predvsem dveh ključnih mož: Neronovega vzgojitelja Seneke in pretorijanskega prefekta Afranija Bura (Afranius Burrus). Oba sta svoj položaj dobila zgolj zaradi posredovanja Agripine, vendar kljub temu po Klavdijevi smrti nista bila izvrševalca Agripinine volje. Tacit celo poroča, da sta se ji oba vse od prvega dne Neronovega nastopa odkrito upirala. S svojim vplivom sta podprla Nerona, Agripinina moč pa je hitro slabela..$^{38}$

Da željam svoje matere ni več pripravljen ubogljivo slediti, je Neron povsem jasno pokazal, ko si je za priležnico izbral osvobojenko Akte, medtem ko

33 Tacitus, Annales 12.58 .

34 Suetonius, Divus Claudius 43. Na možnost, da bi cesarjev osvobojenec Narcis Klavdija nagovoril, naj svojemu sinu Britaniku podeli enake pravice, kot jih je že imel adoptirani Neron, opozarja Eck, »Iulisch-claudische Familie«,150. Morda je Klavdij nekaj let kasneje obžaloval, da je Nerona tako izpostavil, in je poskušal svojega biološkega sina znova postaviti na prvo mesto; gl. Waldherr, Nero, 49.

$35 \mathrm{O}$ možnosti, da bi Klavdij umrl naravne smrti, gl. Barrett, Agrippina, 139-42.

36 Klavdij je za seboj pustil testament, v katerem je, tako lahko domnevamo, Britaniku namenil večji delež in boljši položaj, kot se je Agripini in Neronu zdelo primerno. Testamenta po Klavdijevi smrti pred senatom niso prebrali; Tacitus, Annales 12.69.3; gl. tudi Koestermannov komentar v Tacitus, Annalen, 230; Malitz, Nero, 18.

37 Tako bi lahko sklepali na osnovi v prvih dneh Neronove vlade skovanega zlatnika, ki je imel na svoji sprednji strani upodobljena portreta Agripine in Nerona, napis na robu zlatnika pa se je glasil: »Agripina avgusta, žena božanskega Klavdija, mati Nerona Cezarja«. Ne le, da žena nekega cesarja pred tem na sprednji strani kovanca še nikoli ni bila upodobljena, tudi napis, kot ga je dala skovati Agripina, so si pred tem lahko privoščili samo cesarji; gl. Eck, »Iulisch-claudische Familie«, 151-53. O vlogi Agripine v prvih tednih Neronove vlade gl. tudi Cizek, L'époque de Néro, 77-78.

38 Tacitus, Annales 13.1-2. 
se za ženo Oktavijo povsem očitno ni več menil..$^{39}$ Agripina je ob spoznanju, da izgublja moč, ki jo je nad sinom nekoč imela, in da tudi sicer njen vpliv nezadržno slabi, posegla po grožnji, zaradi katere je Klavdij pred tem izgubil življenje. Sinu je zagrozila z Britanikom. ${ }^{40}$ To je zadoščalo, da je moral tudi Britanik, Oktavijin brat, kmalu umreti. 11. ali 12. februarja leta 55, torej prav tedaj, ko bi dopolnil štirinajst let in bi lahko postal polnoleten, je bil na Neronov ukaz med obrokom v pričo vseh navzočih zastrupljen. ${ }^{41}$ Zdaj klavdijski rod ni več imel moškega predstavnika, Oktavija pa je po usmrtitvi matere Mesaline ter po umorih očeta Klavdija in brata Britanika na Neronovem dvoru ostala povsem sama. Vendar Oktavija, ki je na lasne oči videla, kako je moral njen brat umreti, ni bila edina izmed navzočih, ki jih je Britanikova smrt globoko pretresla.

Novi umor je prestrašil tudi Agripino, ${ }^{42}$ saj je z Britanikom izgubila možnost, da bi sinu učinkovito grozila, hkrati pa je Neron tedaj prvič pokazal, da se niti sam ne boji moriti. Kmalu po umoru Britanika je Neron materi odvzel telesno stražo in oddelek Germanov, do katerih je imela pred tem kot cesarjeva žena in cesarjeva mati pravico, zapustiti pa je morala tudi palačo na $\mathrm{Pa}$ latinu. ${ }^{43}$ Zdaj je vsakomur lahko postalo jasno, da so Agripinini dnevi minili in v državi znova vlada moška roka. Takšen preobrat, do katerega je prišlo samo približno šest mesecev po Klavdijevem umoru, je ponudil Agripininim sovražnikom - in teh ni bilo malo - priložnost za njihovo lastno maščevanje. Domicija, sestra leta 54 na Agripinino pobudo usmrčene Domicije Lepide, ${ }^{44}$ in Junija Silana, ${ }^{45} \mathrm{ki}$ ji je Agripina preprečila načrtovano poroko, ${ }^{46}$ sta s svojim govorjenjem dosegli, da je bila Agripina obtožena snovanja zarote. ${ }^{47}$ Ovadba se je sicer izkazala za lažno, vendar pa Agripina kljub dokazani nedolžnos-

39 Tacitus, Annales 13.12-13. Kot poroča Svetonij (Nero 28.1), naj bi se Neron z Akte celo nameraval poročiti; gl. tudi Cassius Dio 61.7.1.

40 Tacitus, Annales 13.14; gl tudi Waldherr, Nero, 73-75. Ob tem Agripina najverjetneje nikoli ni razmišljala o tem, da bi sina odstranila z oblasti, saj bi njegov padec pomenil tudi konec uresničenja njenih lastnih ambicij; gl. Cizek, L'époque de Néro, 89; Barrett, Agrippina, 169.

41 Pseudo-Seneca, Octavia, 45-46; Tacitus, Annales 13.16-17; Cassius Dio 61.7.4. Možnost, da Neron ni bil kriv za Britanikovo smrt, nekoliko podrobneje predstavljata Cizek, L'époque de Néro, 8991; Barrett, Agrippina, 171-72.

42 Tacitus, Annales 13.16.4; Pseudo-Seneca, Octavia 170-73.

43 Tacitus, Annales 13.18; Suetonius, Nero 34.1.

44 Domicija Lepida je bila po svoji materi, Antoniji Starejši, vnukinja Marka Antonija in Avgustove sestre Oktavije ter pranečakinja cesarja Avgusta, bila je mati Klavdijeve žene Valerije Mesaline in tako Britanikova in Oktavijina babica, kot sestra Gneja Domicija Ahenobarba, Neronovega očeta, pa je bila tudi Neronova teta. V času, ko je bila Agripina v izgnanstvu, je Neron po očetovi smrti živel v njeni hiši. Po Agripinini poroki s cesarjem Klavdijem je poskušala Domicija Lepida $\mathrm{z}$ darili in ljubeznivostmi Nerona znova tesneje navezati nase, kar je Agripina preprečila tako, da je z lažnimi obtožbami dosegla njeno usmrtitev (Tacitus, Annales 12.64-65). O večletnih zaostrenih odnosih med obema ženama, ki so po Mesalinini usmrtitvi prerasli v nespravljivo sovraštvo, gl. tudi Waldherr, Nero, 40.

45 Rod Junije Silane nam ni zanesljivo poznan, kljub svojemu imenu pa ni bila hči Marka Junija Silana Torkvata in Emilije Lepide.

46 Razloge za sovraštvo, ki sta ga do Agripine čutili Domicija in Junija Silana, podrobneje navaja Barrett, Agrippina, 174-75.

47 Tacitus, Annales 13.19-21. Po Britanikovi smrti je Agripina povsem odkrito stopila na Oktavijino stran ter navezala stike $\mathrm{z}$ delom plemstva, ki je nasprotovalo Neronovi oblasti; gl. Waldherr, Nero, 76. 
ti nikoli več ni mogla obnoviti svoje moči. Čeprav pisni viri o Agripininem življenju od leta 55 do njene smrti marca 59 skorajda ne poročajo, se zdi, da Agripina sinove oblasti v tem obdobju ni ogrožala..$^{8}$

Domnevamo lahko, da je bila predvsem Popeja Sabina, s katero se je Neron spoznal leta 58 in je veljala za eno največjih lepotic takratnega Rima, razlog za Neronov trdni sklep, da mora tudi njegova mati umreti. Popeja Sabina, ki je bila vsaj šest let starejša od Nerona, je bila v času, ko sta se s cesarjem seznanila, že drugič poročena. Njen tedanji mož, senator Mark Salvij Oton, je pripadal krogu Neronovih razuzdanih prijateljev in je po Neronovi smrti sam za krajši čas postal cesar. Moči Neronove matere Agripine pa Popeja osebno ni občutila šele takrat, ko je kot Neronova priležnica ogrozila Agripinine načrte, temveč že leta 51, ko je Agripina cesarja Klavdija prepričala, da je kot pretorijanskega prefekta odstavil Popejinega prvega moža Krispina in na njegovo mesto postavil Bura. ${ }^{49}$

Po umiku matere Agripine je bila Popeja Sabina edina ženska, ki je na Nerona in njegovo okolico zares usodno vplivala. Z Oktavijo, sodeč po virih, nikoli nista bila tesneje povezana ${ }^{50}$ in tudi ostale ženske, s katerimi se je Neron intimneje zapletel, nanj niso imele večjega vpliva. Drugače kot osvobojenka Akte se Popeja nikakor ni bila pripravljena zadovoljiti z mestom cesarjeve priležnice, temveč je od samega začetka načrtovala, kako bo postala Neronova zakonita žena. A da bi se lahko poročila z Neronom, se je morala najprej ločiti od moža Otona, hkrati pa je moral biti prost tudi Neron. Temu nasproti sta stali dve ženski, Neronova žena Oktavija iz cesarske hiše in njegova mati Agripina. Agripina je videla v Neronovi poroki z Oktavijo dodatno legitimacijo Neronove cesarske oblasti. Poleg tega bi poroka s Popejo izničila vsa njena dotedanja prizadevanja, ki naj bi julijsko-klavdijski dinastiji omogočila, da bi vso oblast zbrala v svojih rokah. Zato Agripina v ločitev nikakor ni bila pripravljena privoliti. Ni povsem jasno, ali je bila le Popeja tista, ki je Nerona nagovorila, da je ubil svojo mater, ${ }^{51}$ ali pa so za dokončno odločitvijo tičali tudi drugi razlogi. Tacit poroča, ${ }^{52}$ kako se je Agripina na koncu, ko je izrabila vse druge možnosti, sinu z namenom, da bi si znova pridobila njegovo naklonjenost, sama ponujala za ljubico. S svojim vsiljevanjem naj bi ga tako zelo obremenjevala, da jo je prav zaradi tega sklenil umoriti, pri čemer naj bi njegov načrt na koncu podprl celo sam Seneka..$^{53}$ Agripina je bila po daljših

48 Eck, »Iulisch-claudische Familie«, 155. O Agripinini vlogi po letu 55 gl. tudi Barrett, Agrippina, 176-8o.

49 Waldherr, Nero, 82-85.

50 Kot poroča Svetonij (Nero 35.1), naj bi Neron kmalu po poroki celo izjavil, da Oktavija od poroke ne more pričakovati več kot pravico, da nosi znamenja, ki označujejo poročeno ženo (ornamenta uxoria); gl. tudi Waldherr, Nero, 97.

51 Da je bila prav Popeja tista, ki je pregovorila Nerona, povsem nedvoumno piše Pseudo-Seneca, Octavia, 125-29.

52 Tacitus, Annales 14.2; gl. tudi Cassius Dio 62[61].11.3-4.

53 O majhni verjetnosti takšnih obtožb gl. Waldherr, Nero, 87. Cizek ne izključuje možnosti, da bi Agripina v tem času Neronovo oblast še vedno lahko resno ogrožala; Cizek, L'époque de Néro, 118. 
in skrbno načrtovanih pripravah umorjena marca leta $59 .{ }^{54}$ Leta $62^{55}$ se je Neron ločil od Oktavije in poročil s Popejo. Ločitev so uradno opravičili z domnevno Oktavijino neplodnostjo, ${ }^{56}$ hkrati pa je bila obtožena ljubimkanja $\mathrm{z}$ egipčanskim flavtistom..$^{57}$ Tako so na že velikokrat preizkušeni način skušali omajati ugled, ki ga je Oktavija uživala med prebivalstvom. ${ }^{8}$ Medtem ko se Oktaviji in Neronu po devetih letih zakona ni rodil niti en otrok, je Popeja Neronu 21. januarja leta 63 rodila deklico, vendar je dojenček že po štirih mesecih umrl. Nato je bila Popeja leta 65 znova noseča. Takrat je Neron z brco v ženin trebuh končal njeno in otrokovo življenje..$^{59}$

Oktavija je bila v tem času že tri leta mrtva. Usmrčena ${ }^{60}$ je bila junija leta 62 na otoku Pandaterija ${ }^{61}$ kamor je bila malo pred svojo smrtjo poslana v izgnanstvo. Ni jasno, ali se je Neron s Popejo poročil šele po njeni smrti ali že pred njo. Razlog za Oktavijin izgon na Pandaterijo je bila obtožba prešuštva z Anicetom, Neronovim nekdanjim učiteljem in Agripininim morilcem. ${ }^{62}$ Anicet, ki je tudi tokrat uslužno izvršil cesarjev ukaz, je bil za svoje

54 Umor Agripine podrobno opisuje Tacit, Annales 14.3-9; gl. tudi Pseudo-Seneca, Oktavia 311-76; Suetonius, Nero 34.2-4; Cassius Dio 62[61].12-13.

55 Na osnovi dejstva, da se je Neron s Popejo poročil šele tri leta po materini smrti, bi lahko domnevali, da Agripina ni bila edini razlog, zaradi katerega se Neron ni mogel ločiti. Poleg Agripine je ločitvi vztrajno nasprotoval pretorijanski prefek Bur, ki je bil Oktaviji zelo naklonjen. Ko je ta leta $62 \mathrm{umrl}$ (Tacitus, Annales 14.51.1), si Neronovi ločitvi od Oktavije in poroki s Popejo nihče več ni upal resno nasprotovati; gl. Waldherr, Nero, 86, 96 in 97. O Burovem nasprotovanju ločitvi gl. tudi Cassius Dio 62.13.1-3. Avtor tragedije Oktavija pa kot ključni razlog, zaradi katerega se je Neron poročil s Popejo, navaja Popejino nosečnost; Pseudo-Seneca, Octavia, 588-92. Ali je bil Bur v času, ko je Popejina nosečnost postala znana, še živ, iz virov ni mogoče zanesljivo razbrati. Vsekakor pa se je razvoj dogodkov po razkritju, da Neron in Popeja pričakujeta otroka, zelo pospešil, saj je bila Oktavija usmrčena le približno mesec dni kasneje.

56 Nejasno ostaja, ali je bil razlog za to, da Naron in Oktavija nista imela otrok, Oktavijina neplodnost ali, kar se zdi skoraj verjetneje, popolna odtujenost med zakoncema; gl. Waldherr, Nero, 97. Da verjetno ni bil le Neron tisti, ki Oktavije nikakor ni bil pripravljen sprejeti, bi morda lahko razkrivala tudi tragedija Oktavija, v kateri besede naslovne junakinje razkrivajo neizmerno in povsem nepomirljivo sovraštvo do Nerona; Pseudo-Seneca, Octavia, 46-54, 108-14, 248-49; gl. tudi op. cit., $537-42$.

57 Tacitus, Annales, 14.6o; Suetonius, Nero 35.1-2; Cassius Dio 62.13.4. Zaradi te obtožbe je bila Oktavija, čeprav ji prešuštva niso mogli dokazati, izgnana v Kampanijo.

58 Waldherr, Nero, 97-98. Kot je celotno dogajanje predstavljeno v Seneki pripisani Oktaviji, naj bi se Neron tudi zaradi velike podpore, ki jo je Oktavija med ljudstvom uživala, odločil Oktavijo ubiti; gl. Pseudo-Seneca, Octavia, 846-76; gl. tudi Cizek, L'époque de Néro, 148-49. O veliki Oktavijini priljubljenosti pri ljudstvu poroča tudi Tacit, ki piše, da je Neron potem, ko je Oktavijo že izgnal v Kampanijo, prav zaradi nasprotovanja ljudstva svoj ukaz preklical in Oktavijo poklical nazaj. Nato pa se je ob vnovičnih neredih, ki so bili posledica ljudske podpore Oktaviji, na Popejino prigovarjanje odločil, da se bo nekdanje žene za vedno rešil na podlagi obtožb, da je prešuštvovala in kovala zaroto; Tacitus, Annales 14.59.3, 14.60.4.-62.1; gl. tudi Suetonius, Nero 35.2 .

59 Tacitus, Annales 16.6; Suetonius, Nero 35.3.

60 O Oktavijini usmrtitvi med nekoliko poznejšimi viri zelo kratko poroča tudi Evtropij (7.14.3).

$61 \mathrm{~V}$ usodi žena julijsko-klavdijske dinastije pripada otoku posebej zlovešče mesto, saj so bile nanj še pred Oktavijo izgnane tudi nekatere druge pomembne predstavnice te družine: Julija, Avgustova hči, leta 2 pr. Kr., Germanikova žena Agripina Starejša leta 29, njena hči, Agripina Mlajša, Neronova mati, in najverjetneje tudi Agripinina sestra Julija Livila pa leta 39. Julija Livila je bila po vrnitvi iz izgnanstva na začetku Klavdijeve vlade leta 41 na otok ponovno izgnana in je na njem še istega leta tudi umrla. Na otoku je že leta 33 umrla tudi njena mati Agripina Starejša.

62 Tacitus, Annales 14.3-8. 
lažno pričanje izgnan na Sardinijo. ${ }^{63}$ Oktavijino usmrtitev so prikazali kot samomor. ${ }^{64}$ Anicet pa je na Sardiniji mirno in udobno živel do konca svojega življenja.

Leta 62, ko je bila usmrčena Oktavija, se je na Neronov ukaz končalo tudi življenje dveh njenih sorodnikov, Rubelija Plavta, Tiberijevega pravnuka, in Favsta Kornelija Sule Feliksa, Mesalininega polbrata in moža Klavdijeve hčerke Antonije. ${ }^{65}$ Potem ko se je Neron ločil od Oktavije, ki je njegovi cesarski oblasti dajala pomemben del legitimnosti, se je bal, da bi se okrog teh dveh mož oblikovalo jedro sovražne opozicije in žarišče morebitnega upora. Prav zaradi tega razloga je bil leta 64 na Neronov ukaz Decim Junij Silan Torkvat, prapravnuk cesarja Avgusta in brat že leta 49 umrlega Lucija Junija Silana, prisiljen napraviti samomor. Naslednjega leta pa je moral iz istega razloga umreti še njegov nečak, Lucij Junij Silan Torkvat. ${ }^{66} \mathrm{Z}$ njuno smrtjo se je zaradi Neronovega strahu pred komerkoli, ki bi utegnil ogroziti njegovo oblast, izteklo življenje še zadnjih moških potomcev cesarja Avgusta. ${ }^{67}$

\section{BIBLIOGRAFIJA}

\section{Seznam virov}

\section{Cassius Dio}

Historia romana. V: Dio’s Roman History in nine volumes. 7. zv., angleški prevod E. Cary. Loeb Classical Library. London: William Heinemann, Cambridge, Massachusetts: Harvard University Press, 1955.

»Epitome de Caesaribus.«gl. Sextus Aurelius Victor.

\section{Eutropius}

»Breviarium ab urbe condita." V: Monumenta Germaniae Historica. Auctores Antiquissimi 2, izdaja H. Droysen. München: Monumenta Germaniae Historica, 2000.

\section{Ioannes Zonaras}

Annales. V: Ioannis Zonarae Annales. 2. zv, izdaja Mauricius Pinderus. Corpus Scriptorum Historiae Byzantine 48. Bonnae: Ed. Weber, 1844.

63 Tacitus, Annales, 14.62-63. Tacit navaja, kako je ob tej priložnosti Neron Oktavijo povsem v nasprotju s prejšnjimi očitki obtožil, da je splavila.

64 Tacitus, Annales, 14.64.

65 Gl. tudi Pseudo-Seneca, Octavia 437-38, 464-68.

66 Kot Avgustov prapravnuk je moral zaradi nevarnosti, da bi lahko ogrozil Neronovo oblast, skoraj neposredno po Klavdijevi smrti že leta 54 umreti tudi najstarejši brat že leta 49 umrlega Lucija Junija Silana in Decima Junija Silana Torkvata, Mark Junij Silan, ki je bil leta 46 konzul in v času, ko je bil na Agripinin ukaz umorjen, prokonzul province Azije. O njegovi usmrtitvi gl. Waldherr, Nero, 64.

67 Waldherr, Nero, 98-100. 
Pseudo-Seneca

Octavia. V: Octavia, attributed to Seneca. Izdaja, uvod, prevod in komentar A.J. Boyle. Oxford, New York: Oxford University Press, 2008.

\section{Seneca, Lucius Annaeus}

Apocolocyntosis divi Claudii. V: »Potikvitev. Satira na cesarja Klaudija smrt, vnebohod in pot v pekel.« Prev. A. Sovre. V: Svet humorja in satire, ur. D. Ravljen. Ljubljana: Društvo novinarjev Slovenije, 1951, 9-23.

Sextus Aurelius Victor

De Caesaribus. V: Sexti Avrelii Victoris Liber de Caesaribus: praecedunt Origo gentis romanae et Liber de viris illustribus Urbis Romae subsequitur Epitome de Caesaribus, izdaja Fr. Pichlmayr. Bibliotheca Scriptorum Graecorum et Romanorum Teubneriana. Lipsiae: B.G. Teubner, 1966.

De Caesaribus. Angleški prevod z uvodom in komentarjem H.W. Bird. Translated Texts for Historians 17. Liverpool: Liverpool University Press, 1994.

\section{Suetonius}

De vita Caesarum. V: Suetonius, 2. zv., angleški prevod J.C. Rolfe. Loeb Classical Library. Cambridge, Massachusetts, London: Harvard University Press, 2001.

De vita Caesarum. V: Suétone, Vies des douze césars, 2. zv., izdaja in prevod H. Ailloud. Collection des universités de France. Paris: Les belles lettres, 1993.

Dvanajst rimskih cesarjev. Slovenki prevod in opombe J. Šmit. Ljubljana: Cankarjeva založba 1960.

\section{Tacitus, Publius Cornelius}

Annales. Izdaja E. Koestermann. Bibliotheca Scriptorum Graecorum et Romanorum Teubneriana. Lipsiae: B.G.Teubner, 1952.

Annalen. 3. zv., knjige 11-13. Komentar in uvod E. Koestermann. Heidelberg: Carl Winter Universitätsverlag, 1967.

Annalen. 4. zv., knjige 14-16. Komentar in uvod E. Koestermann. Heidelberg: Carl Winter Universitätsverlag, 1968.

Anali. Slovenski prevod F. Bradač. Maribor: Založba Obzorja, 1968.

\section{Seznam literature}

Barrett, Anthony A. Agrippina. Mother of Nero. London: B T Batsford Ltd, 1996.

Cizek, Eugen. L'époque de Néron et ses controverses idéologiques. Roma aeterna 4. Leiden: E. J. Brill, 1972.

Eck, Werner. "Die iulisch-claudische Familie: Frauen neben Caligula, Claudius und Nero." V: Die Kaiserinnen Roms. Von Livia bis Theodora, ur. Hildegard Temporini in Gräfin Vitzthum, 103-63. München: Verlag C.H.Beck, 2002.

Kienast, Dietmar. Römische Kaisertabelle. Grundzüge einer römischen Kaiserchronologie. 3. izd. Darmstadt: Wissenschaftliche Buchgesellschaft, 2004.

Malitz, Jürgen. Nero. München: Beck, 1999.

Shotter, David. Nero. 2. izd. London, New York: Routledge, 2005.

Waldherr, Gerhard H. Nero. Eine Biografie. Regensburg: Verlag Friedrich Pustet, 2005. 


\section{THE HISTORICAL BACKGROUND TO THE PSEUDO- SENECAN OCTAVIA}

\section{Summary}

The paper presents the historical background of the Pseudo-Senecan play Octavia. The work of an unknown author, it depicts the sad fate of Nero's first wife and daughter of Claudius, Octavia, who was exiled because of Nero's impending marriage to Poppaea Sabina and soon executed in exile. As to the protagonists' destinies, the basic plot largely follows the accounts of the extant historical sources, except for the length of the action, which is reduced to three days; in point of fact, the precise sequence of the events concerning Nero's marriage to Poppaea and divorce from Octavia is unknown. Since the extant sources on Octavia's life are few and provide little information, the details of her destiny remain unclear.

The historical background of the play, the developments at the Roman court affecting Octavia, extends from the year 48, when Octavia's engagement to Lucius Junius Silanus was broken off in anticipation of Agrippina's marriage to Emperor Claudius early in 49, to be followed by a new engagement to Agrippina's son, the later Emperor Nero, to 62, when Nero's planned marriage to Poppaea Sabina led to Octavia's exile and speedy execution on a false charge of adultery. In this temporal frame, the paper highlights the following milestones in Octavia's life: Agrippina's appointment of the philosopher Lucius Annaeus Seneca as tutor to her son Domitius (later known as Nero) in 49 AD; Claudius' adoption of Agrippina's son on 25 February 50 $\mathrm{AD}$; the proclamation of thirteen-year-old Nero's coming of age in March 51; Nero's marriage to Octavia in 53; the death of Claudius and Nero's rise to power in 54; Nero's murder of Britannicus in 55, and of his mother, Agrippina, four years later (59); Nero's affair with Poppaea Sabina, whom he had met in 58 , and their wedding in 62 , as well as Octavia's exile and execution in the same year. But despite the close bearing of these events on Octavia's fate, she is largely or completely ignored in most written sources on the topic. Rather than attempt to disentangle the many questions raised by Octavia's little known life, the paper thus gives a mere outline of her life story, trapped in the dynastic intrigues of the contemporary Roman court, which are luridly depicted in the tragedy Octavia, formerly attributed to Seneca. 